\title{
Refrigeration and modified atmosphere to the conservation of 'Malasia' Star fruit
}

\author{
Rafaely das Chagas Lameira ${ }^{1}$ (D) Bárbara Marçon Pereira da Silva ${ }^{1}$ (iD \\ Silvia Regina de Toledo Valentini ${ }^{2}$ (D) Patrícia Cia ${ }^{2}$ ID Ilana Urbano Bron ${ }^{2 *}$ (D)
}

${ }^{1}$ Programa de Pós-graduação em Agricultura Tropical e Subtropical, Instituto Agronômico (IAC), Campinas, SP, Brasil.

${ }^{2}$ Laboratório de Pós-Colheita, Instituto Agronômico (IAC), 13075-630, Campinas, SP, Brasil. E-mail: ilana@iac.sp.gov.br. "Corresponding author.

ABSTRACT: Despite the fact that cold storage and modified atmosphere techniques have already been studied for fresh cut Star fruit, little has been done considering the whole fruit. Besides that, each cultivar has its peculiarities, so the efficiency of combined postharvest treatments should be studied. The objective of this study was to evaluate the effect of polyvinyl chloride (PVC), $8.5 \mu \mathrm{m}$ thick and low-density polyethylene (LDPE), $33 \mu \mathrm{m}$ thick associated with cold storage $\left(10 \pm 1{ }^{\circ} \mathrm{C}\right.$ and $\left.5 \pm 1{ }^{\circ} \mathrm{C} / 85 \pm 5 \% \mathrm{RH}\right)$ on the conservation of 'Malasia' Star fruit. Storage at $25^{\circ} \mathrm{C}$ maintained Star fruit overall quality, regardless of the film type, up to four days. The weight loss was higher in fruit packed with PVC, but this fact was not noticed by the sensory analysis. The storage in 5 and $10^{\circ} \mathrm{C}$ did not caused chilling injury but fruit presented retention of yellow color development and firmness reduction; these aspects were positively assessed by the sensory analysis. The film type did not influence the conservation of the fruit. The storage at 5 and $10^{\circ} \mathrm{C}$, regardless of the package film, prolonged 'Malasia'star fruit shelf life up to 16 days, followed by two days at $25^{\circ} \mathrm{C}$.

Key words: Averrhoa carambola L., films, postharvest, ripening.

Refrigeração e atmosfera modificada na conservação da carambola 'Malasia'

RESUMO: Apesar das técnicas de armazenamento refrigerado e atmosfera modificada já terem sido estudadas para carambolas processadas, pouco foi feito considerando a fruta inteira. Além disso, cada cultivar possui peculiaridades, dessa forma a eficiência dos tratamentos póscolheita combinados deve ser estudada. O objetivo deste trabalho foi avaliar o efeito do cloreto de polivinila (PVC), 8,5 $\mu$ m de espessura e polietileno de baixa densidade (PEBD), $33 \mu \mathrm{m}$ de espessura associados ao armazenamento refrigerado $\left(10 \pm 1{ }^{\circ} \mathrm{Ce} 5 \pm 1{ }^{\circ} \mathrm{C} / 85 \pm 5 \%\right.$ de UR) na conservação da carambola Malasia. O armazenamento a $25^{\circ} \mathrm{C}$ manteve a qualidade da carambola, independentemente do tipo de filme, até quatro dias. A perda de massa foi maior nos frutos embalados em PVC, mas esta não foi percebida pela análise sensorial. As temperaturas de armazenamento de 5 e $10{ }^{\circ} \mathrm{C}$ não causaram dano de frio, mas os frutos apresentaram retenção no desenvolvimento da coloração amarela e na redução da firmeza; esses aspectos foram avaliados positivamente na análise sensorial. O tipo de filme não influenciou a conservação do fruto. O armazenamento a 5 e $10^{\circ} \mathrm{C}$, independente do filme da embalagem, prolongou a vida útil da carambola 'Malasia' até 16 dias, seguido por dois dias a $25^{\circ} \mathrm{C}$.

Palavras-chave: Averrhoa carambola L., filmes, pós-colheita, amadurecimento.

\section{INTRODUCTION}

Star fruit (Averrhoa carambola L.) is an economical alternative to traditional fruit crops due to its high profitability both at Brazilian and international market. However, the shelf life of Star fruit is short due to its rapid dehydration and browning. Low temperature storage extends the storability of star fruit. However, there is no consensus about the recommended temperature for this fruit. According to ALI et al. (2004), storage at 5 and $10{ }^{\circ} \mathrm{C}$ caused chilling injury in 'B-10' star fruit. CAMPBELL \&
KOCH (1989) pointed out that 'Golden Star' star fruit stored at $5{ }^{\circ} \mathrm{C}$ maintained better appearance and ripened normally when compared to those stored at $10^{\circ} \mathrm{C}$. According to $\mathrm{CHEN}$ et al. (2017) temperatures of $5{ }^{\circ} \mathrm{C}$ maintained 'Honglong' star fruit quality whereas storage temperatures of 0 and $3{ }^{\circ} \mathrm{C}$ caused severe chilling injury. When stored at $10{ }^{\circ} \mathrm{C}$ the fruits quality was not preserved and it presented high diseases incidence.

The modified atmosphere (MA) associated to refrigeration could be beneficial to avoid chilling injury and excessive transpiration and enzymatic 
browning. In retail trade, the most used film is PVC (polyvinyl chloride); however, it generally promotes little change in the dynamics of gas levels inside the packages. NEVES et al. (2004) obtained better conservation for Star fruit packed in low-density polyethylene (LDPE) film $10 \mu \mathrm{m}$ at $12{ }^{\circ} \mathrm{C}$ for 45 days. When packed in $15 \mu \mathrm{m}$ LDPE film, the fruit lost firmness, probably due to physiological disorders. In the study of CRUZ et al. (2001), a proper conservation of Star fruit, stored at $12{ }^{\circ} \mathrm{C}$, was achieved using LDPE $50 \mu \mathrm{m}$ thick. Even though refrigeration and modified atmospheres have already been studied for fresh cut star fruit, little has been done considering the whole fruit. Moreover, we found differences in postharvest physiology among cultivars from the same species. Therefore, the efficacy of combined treatments should be studied in each cultivar. In this context, the aim of this study was to evaluate the potential conservation of 'Malasia' star fruit under refrigeration $\left(10 \pm 1^{\circ} \mathrm{C}\right.$ and $\left.5 \pm 1^{\circ} \mathrm{C}\right)$, associated with passive modified atmosphere (polyvinyl chloride 8.5 $\mu \mathrm{m}$ thick and low-density polyethylene $33 \mu \mathrm{m}$ thick), in order to extend the fruit conservation.

\section{MATERIALS AND METHODS}

'Malasia' star fruits were harvested at stage $3 \quad(25-75 \%$ of yellow color visually assessed) from a commercial orchard in Pedra Branca-SP, Brazil. The fruits were conducted to the Agronomic Institute (IAC) in Jundiaí (SP) and packed in polystyrene trays (three fruit per tray) with two different films: polyvinyl chloride (PVC) $8.5 \mu \mathrm{m}$ thick $\left(\mathrm{O}_{2} \mathrm{TR} / \mathrm{CO}_{2} \mathrm{TR}=9,490 / 72,121 \mathrm{ml} . \mathrm{m}^{-2}\right.$. day $^{-1}$; WVTR $=403.4$ g.m . $^{-2}$ day $\left.^{-1}\right)$ and low-density polyethylene (LDPE) $33 \mu \mathrm{m}$ thick $\left(\mathrm{O}_{2} \mathrm{TR} / \mathrm{CO}_{2} \mathrm{TR}\right.$ $=9,300 / 36,548 \mathrm{ml} \cdot \mathrm{m}^{-2} \cdot$ day $^{-1} ; \quad \mathrm{WVTR}=19.2 \mathrm{~g} \cdot \mathrm{m}^{-2}$. day $\left.^{-1}\right)$. The trays with LDPE film were sealed with a pedal sealer (Selasplat), while the trays with PVC were manually wrapped. After packing, fruit of each treatment were stored at $25 \pm 1{ }^{\circ} \mathrm{C}, 10 \pm 1{ }^{\circ} \mathrm{C}$ and $5 \pm 1{ }^{\circ} \mathrm{C}$ with $85 \pm 5 \%$ of relative humidity $(\mathrm{RH})$ up to 26 days. Every four days, three trays of each treatment stored at 5 and $10{ }^{\circ} \mathrm{C}$ were weighed and the percentage of $\mathrm{CO}_{2}$ and $\mathrm{O}_{2}$ was measured with a gas analyzer (PBI-Dansensor, Check Mate). After that, these trays were transferred to $25 \pm 1{ }^{\circ} \mathrm{C} / 85 \pm 5 \%$ $\mathrm{RH}$ for two days, to simulate the marketing period. Fruit stored at $25^{\circ} \mathrm{C}$ were evaluated on alternate days. After the marketing period, another gas composition evaluation was performed with the packages closed. Fruit were assessed for quality attributes once the packages were opened.
Firmness was evaluated with manual penetrometer (Efegi, model FT-327) with $8 \mathrm{~mm}$ cylindrical tip, on the equatorial opposite sides of the fruit, and expressed as Newtons (N). Soluble solids content (SS) were determined with refractometer (ATTO-2WAJ) and expressed as ${ }^{\circ}$ Brix. Titratable acidity (TA) was determined by $\mathrm{NaOH}$ titration expressed as \% citric acid and ascorbic acid content was determined by DCFI titration to persistent pink coloration for 15 seconds and expressed in mg ascorbic acid per $100 \mathrm{~g}$ pulp according to CARVALHO et al. (1990). Fruit skin color was evaluated with a color reader (Konica Minolta, model CR-10), (scale L, C, ${ }^{\circ} \mathrm{H}$ ), taking two readings on equatorial opposite sides of the fruit. Weight loss was also measured and the results were expressed in percentage. Rot incidence was evaluated by counting the number of fruit with symptoms and expressed as percentage. Fruit browning was assessed visually according to a scale: 1 - fruit with no browning; 2 - up to $30 \%$ of browning skin; 3 from 31 to $60 \%$ of browning skin; 4 - from 61 to $90 \%$ of browning skin; 5 - more than $91 \%$ of browning skin. Sensory analysis was carried out by 30 non-trained panelists who evaluated, by scoring a structured mixed scale questionnaire the following quality attributes: general appearance, color, taste, flavor and acceptability, where $5=$ Much stronger than ideal; $4=$ Stronger than ideal; $3=$ Ideal; $2=$ Weaker than ideal; $1=$ Much weaker than ideal

The experimental design was completely randomized in a triple factorial arrangement (2 types of film $x 3$ storage temperatures $x$ days of storage). For the physical and chemical analysis 3 repetitions were used, each repetition consisting of a tray containing three fruits. The results were submitted to analysis of variance (ANOVA) and means compared by Tukey test at $5 \%(\mathrm{P} \leq 0.05)$ using Assistat 7.6 software.

\section{RESULTS}

The films had no significant effect on fruit color and firmness loss at 5, 10 or $25{ }^{\circ} \mathrm{C}$ (Figure $1 \mathrm{~A}-1 \mathrm{~F})$. Fruit firmness decreased during the storage at $25{ }^{\circ} \mathrm{C}$ reaching values of $10.5 \mathrm{~N}$ on the $8^{\text {th }}$ day $(\mathrm{P} \leq 0.05)$ (Figure 1C). The temperature of cold storage influenced the fruit firmness loss during the marketing period. After 24 days of storage at $5{ }^{\circ} \mathrm{C}$ followed by marketing period, Star fruits had $12.4 \mathrm{~N}$ of firmness, while those that were stored at $10{ }^{\circ} \mathrm{C}$ reached $8.2 \mathrm{~N}$ at the same date $(\mathrm{P} \leq 0.05)$ (Figure $1 \mathrm{~A}$ and $1 \mathrm{~B})$.

The fruit stored at $25^{\circ} \mathrm{C}$ showed a reduction in the Hue angle from $98.9^{\circ} \mathrm{H}$ to $69.5^{\circ} \mathrm{H}$ on the sixth day, indicating yellowing (Figure $1 \mathrm{~F}$ ). Up to the $16^{\text {th }}$ day of 


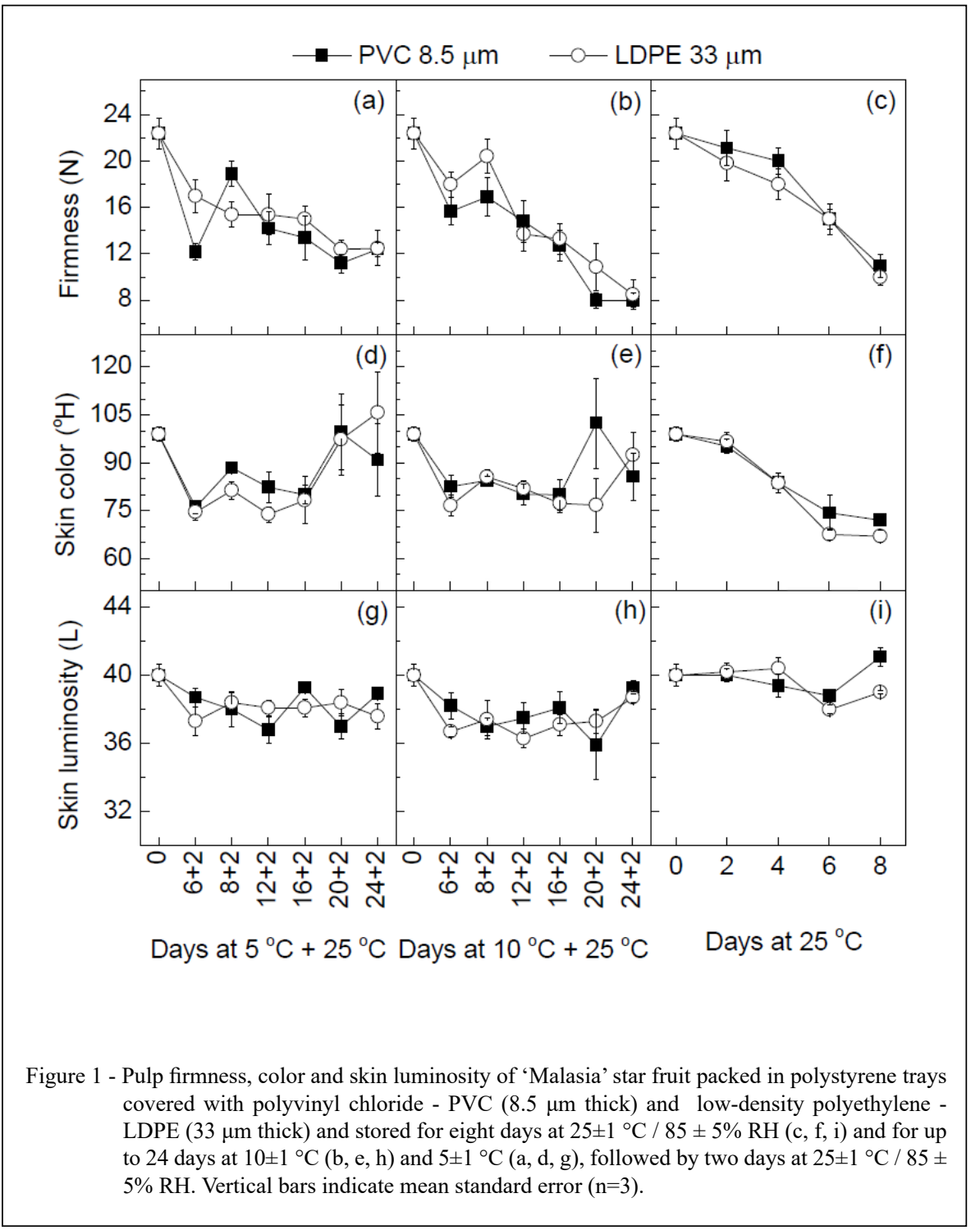

cold storage, the color of the fruit changed from green to yellow $\left(98.9^{\circ} \mathrm{H}\right.$ to $\left.79.0{ }^{\circ} \mathrm{H}\right)$ after the marketing period $(\mathrm{P} \leq 0.05)$. This yellowing during the marketing period was not so evident in those fruit maintained under refrigeration for a longer period, even after the marketing period (Figure 1D and 1E).

There was no significant difference in luminosity ( $\mathrm{L}$ value) during the storage at 25 ${ }^{\circ} \mathrm{C}$ (Figure 1I), and also during the cold storage, indicating that browning was not observed for this cultivar (Figure $1 \mathrm{G}$ and $1 \mathrm{H}$ ).

Considering the entire period of this study, few variations were observed in the titratable acidity, soluble solids, ascorbic acid content and ratio of the fruit from the different treatments. The mean values were $0.23 \%$ of citric acid, $7.7^{\circ}$ Brix of SS, $50 \mathrm{mg} 100$ $\mathrm{g}^{-1}$ of ascorbic acid, 30.6 of ratio (data not shown).

Gas composition inside the packages changed significantly from the second day of storage at $25^{\circ} \mathrm{C}$. After eight days at $25^{\circ} \mathrm{C}$, the concentration of $\mathrm{O}_{2}$ and $\mathrm{CO}_{2}$ inside PVC packages was $15.4 \%$ and $2.2 \%$, respectively $(\mathrm{P} \leq 0.05)$ (Figure $2 \mathrm{C}$ and $3 \mathrm{C}$ ), while in the LDPE packages these values were $6.0 \%$ and $5.1 \%$, respectively $(\mathrm{P} \leq 0.05)$ (Figure $2 \mathrm{~F}$ and $3 \mathrm{~F}$ ).

Minor changes occurred in the gas composition of the packages with PVC and LDPE maintained under refrigeration (Figures 2A, 2B, 2D, $2 \mathrm{E}$ and $3 \mathrm{~A}, 3 \mathrm{~B}, 3 \mathrm{D}, 3 \mathrm{E})$, but this inner atmosphere 


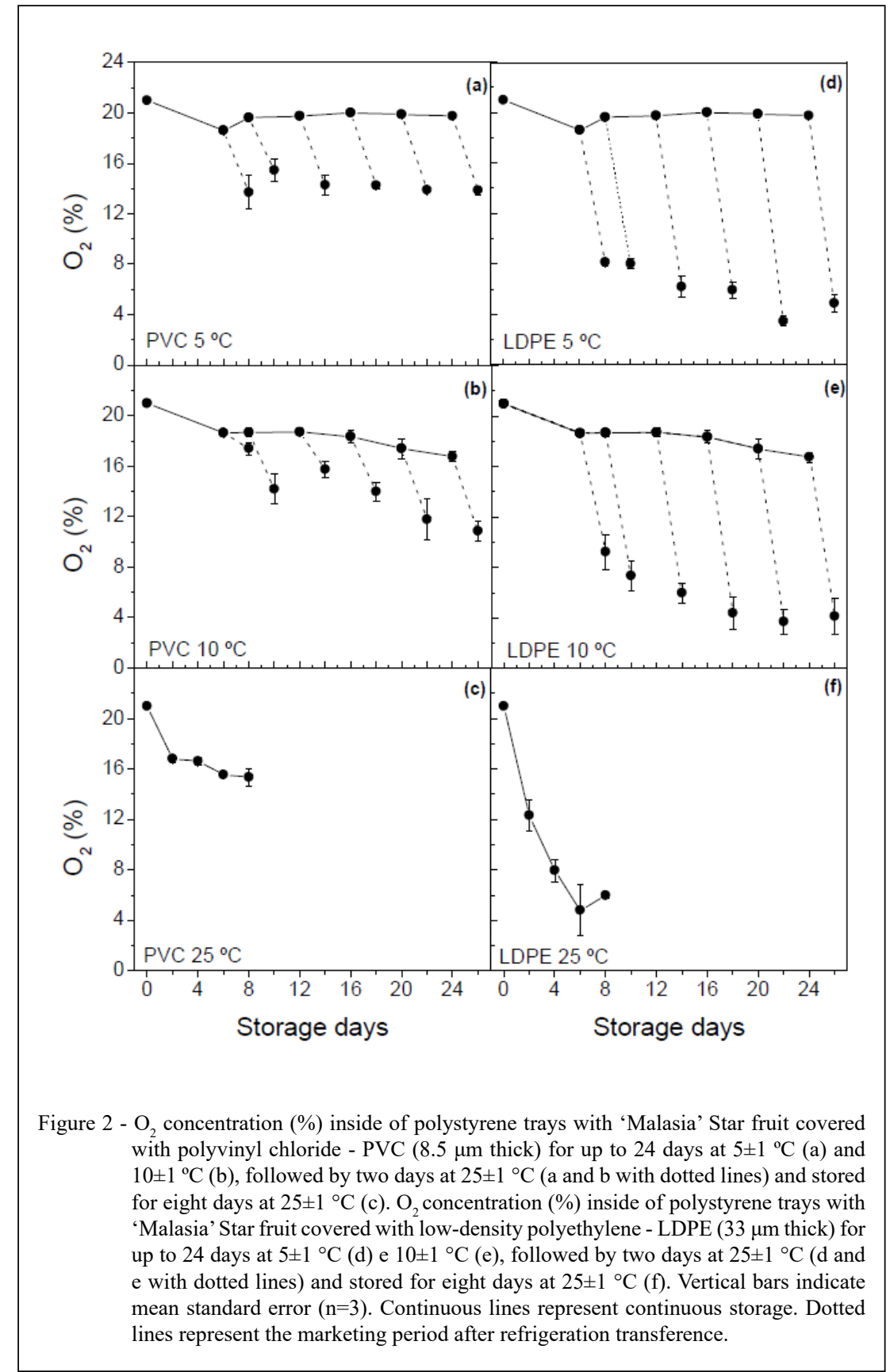

had significant changes when transferred to marketing conditions, mainly in those packed with LDPE. The $\mathrm{O}_{2}$ and $\mathrm{CO}_{2}$ concentration on the eighth day of evaluation was 9.0 and $4.0 \%$, approximately (Figure 2D, E and 3D, E).

On the eighth day at $25{ }^{\circ} \mathrm{C}$, fruit packed with PVC presented $6.6 \%$ of weight loss (Figure $4 \mathrm{C}$ ), whereas those fruit packed with LDPE had only $0.4 \%$
$(\mathrm{P} \leq 0.05)$ (Figure 4F). During refrigeration, fruit packed with PVC also showed higher weight loss compared to the ones packed with LDPE, mainly in those fruit stored at $5{ }^{\circ} \mathrm{C}$ (Figure $4 \mathrm{~A}$ ), corresponding to $5.4 \%$ after 24 days, whereas fruit stored at $10^{\circ} \mathrm{C}$ presented loss of $2.9 \%(\mathrm{P} \leq 0.05)$ (Figure 4B). Lower weight loss of the Star fruit packed with LDPE continued also during the marketing period (Figure 4D and 4E). 


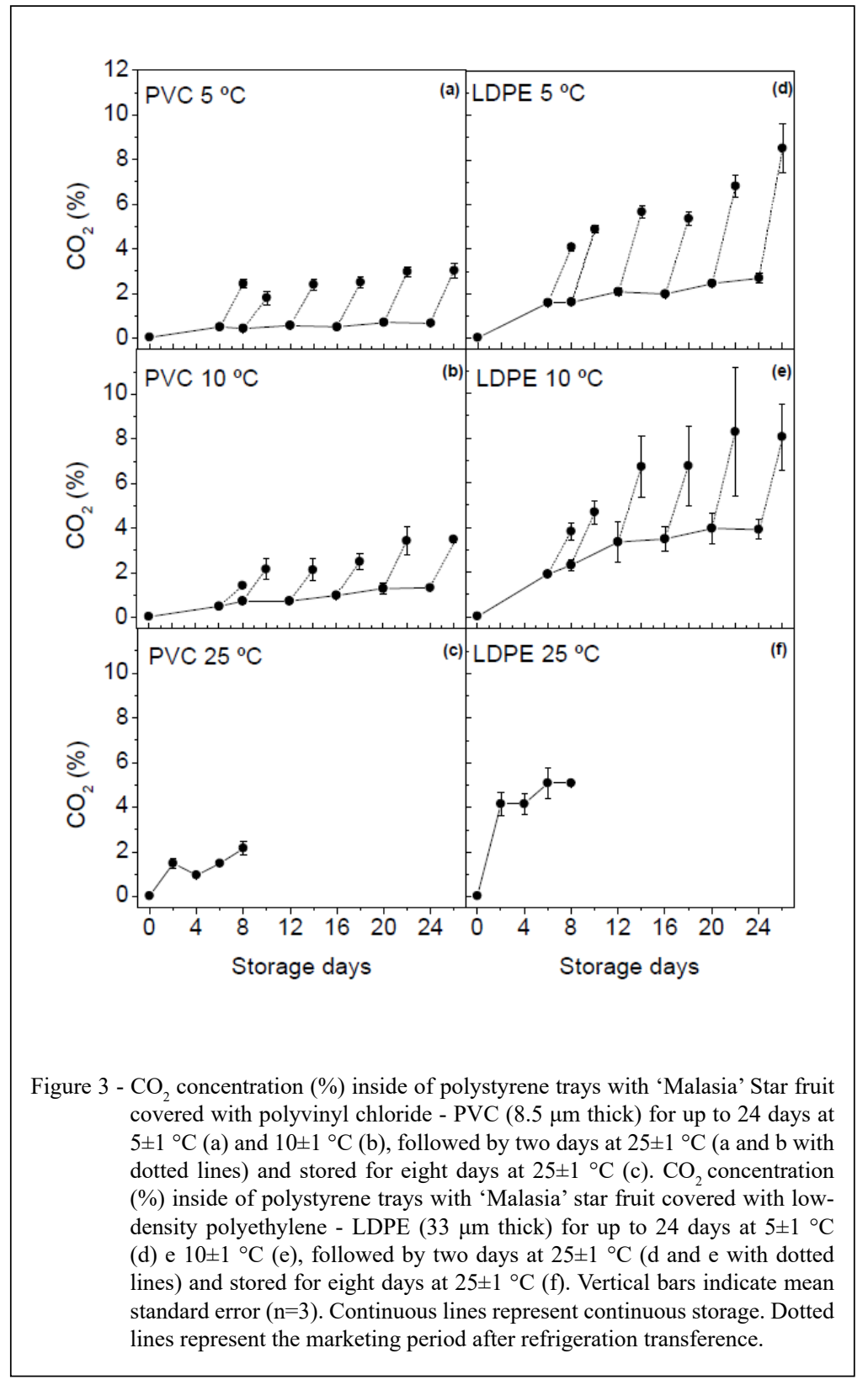

On the sixth day of storage at $25{ }^{\circ} \mathrm{C}, 33 \%$ of the fruit had rot symptoms (Figure $5 \mathrm{C}$ ), regardless of the film used $(\mathrm{P}>0.05)$. By the end of the storage, fruit packed with LDPE had $89 \%$ of disease incidence, while those packed in $\mathrm{PVC}$ had $67 \% \quad(\mathrm{P} \leq 0.05)$ (Figure $5 \mathrm{C}$ ). Fruit stored at $5{ }^{\circ} \mathrm{C}$ did not show any rot symptoms during the marketing period, even after 12 days under refrigeration (Figure $5 \mathrm{~A}$ ), regardless of the film. On the same date, fruit at $10^{\circ} \mathrm{C}$ and packed with LDPE showed $11.1 \%$ of rot (Figure $5 \mathrm{~B}$ ), whereas those with PVC had no disease incidence. From the $20^{\text {th }}$ day of refrigeration, an increase of rot incidence was evident during the marketing period, regardless of the temperature and the film (Figure 5A and 5B).

For subjective evaluation of skin browning in 'Malasia' star fruit, no significant differences were observed among the storage temperatures and the films, with no more than $30 \%$ of browning.

According to the sensorial analysis, the fruits stored at $25{ }^{\circ} \mathrm{C}$ and packed with both films received inferior notes from the sixth day of evaluation, mainly regarding the appearance, color and aroma (Figure 6C, 


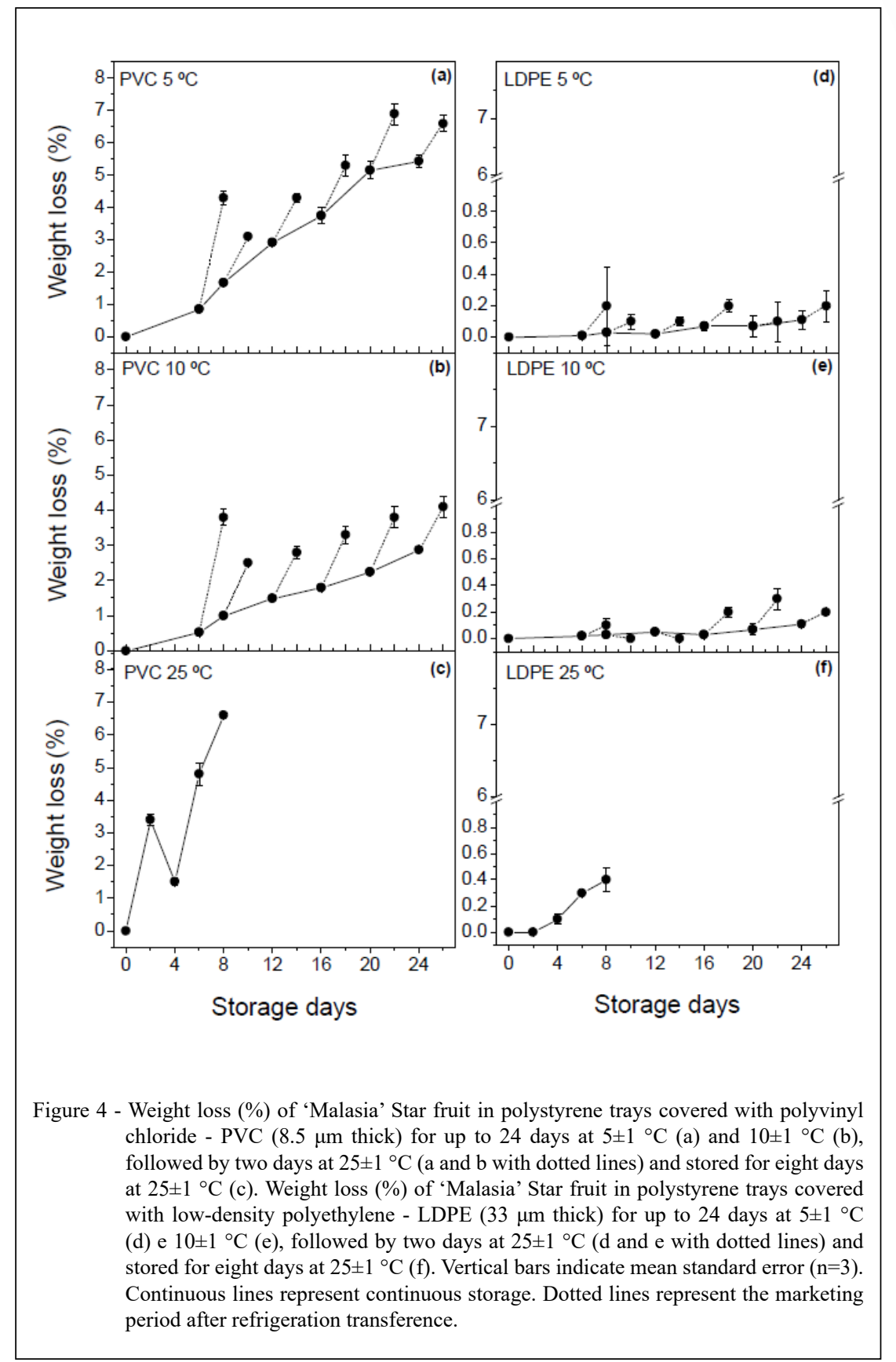

$6 \mathrm{~F}$ and $6 \mathrm{~L}$ ). Cold stored fruits packaged with LDPE had a better evaluation of flavor (3.5) when compared to those packaged with PVC (3.0) $(\mathrm{P} \leq 0.05)$ (Figure 6G and $6 \mathrm{H})$. When compared the two cold temperatures, the temperature of $5{ }^{\circ} \mathrm{C}$ better preserved the fruit aroma, according to the sensorial analysis (Figure 6 J and $6 \mathrm{~K})$. The packaging with both films did not affect fruit acceptability (Figure 6M, 6N and 6O).

\section{DISCUSSION}

There was no difference in fruit preservation when comparing both films. Changes in star fruit ripening process are the main effect of modified atmospheres, as reported by other studies. According to WAN \& LAM (1984), there was a delay in color development of star fruit packed with polyethylene, 


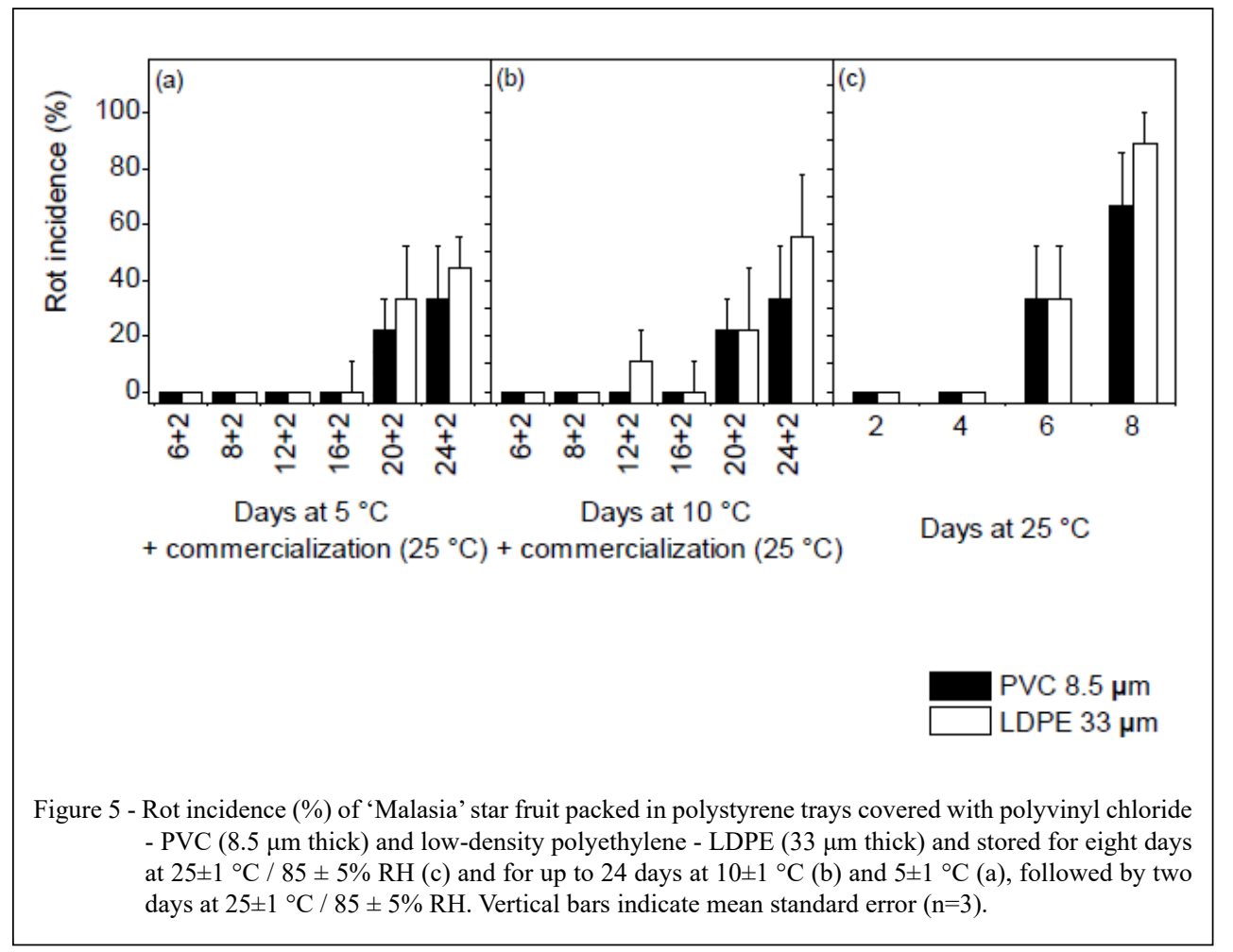

after 7 days at $20{ }^{\circ} \mathrm{C}$, with concentrations of 2.5 $4.5 \%$ of $\mathrm{CO}_{2}$ and $15 \%$ of $\mathrm{O}_{2}$. REVEL \& THOMPSON (1994) observed retention in color development and firmness loss of star fruit stored at $7{ }^{\circ} \mathrm{C}$ only when the gas composition was 2 to $4 \% \mathrm{O}_{2}$ and $8 \%$ of $\mathrm{CO}_{2}$. Due to the difference in its gas permeability, packages with LDPE film presented more significant changes in gas concentration, when compared to those with PVC film $(\mathrm{P} \leq 0.05)$ (Figure 2 and 3 ); however, it was not sufficient to affect the fruit ripening. The only advantage in using LDPE was a reduced weight loss, compared to PVC (Figure. 4) $(\mathrm{P} \leq 0.05)$. However, this lower weight loss was not evident in sensory analysis (Figure 6) (no symptoms of visual dehydration were observed in fruits) and may not be significant in marketing as well. NEVES et al. (2004) evaluated 'Golden Star' star fruit stored for 27 days at $12{ }^{\circ} \mathrm{C}$, without modified atmosphere, and observed a reduction of $61 \%$ in fruit weight. CRUZ et al. (2001), studying the effect of two packages in star fruit conservation, observed that fruit packed in LDPE $50 \mu \mathrm{m}$ thick presented almost zero percentage of weight loss during storage at $10^{\circ} \mathrm{C}$. TEIXEIRA \& DURIGAN (2006), observed $7.8 \%$ of loss in star fruit 'Fwang Tung' after nine days at $21{ }^{\circ} \mathrm{C}$, the authors also reported no visible dehydration in the fruit. A disadvantage with the use of LPDE film was the higher rot incidence in fruit packed with this film (Figure 5) after 12 days of storage $(\mathrm{P} \leq 0.05)$. In the present research, water vapor condensation in LDPE packages was observed, which may have contributed to higher disease incidence. The fourth day of storage at $25^{\circ} \mathrm{C}$ was considered the deadline for marketing. At the sixth day, fruit presented $33 \%$ of incidence regardless of the film used $(\mathrm{P}>0.05)$. Anyway, after 20 days of storage, all the fruits presented high disease incidence (Figure 5); therefore, the type of the film was irrelevant at the end of the storage.

Concentrations of $\mathrm{O}_{2}$ and $\mathrm{CO}_{2}$ presented in this research did not cause quality damage in the fruits. Star fruit did not show any off-flavors during the storage (Figure 6). Although, fruit packed in LDPE presented greater alterations in gas composition, no effects in the main quality characteristics were observed when compared to those packed in PVC.

The temperature was the factor that influenced the fruit conservation, regardless of the film used. It is possible to affirm that, for those fruit maintained at 25 ${ }^{\circ} \mathrm{C}$, sensory analysis demonstrated better quality until the sixth day of evaluation (Figure 6). For the refrigerated ones, quality was considered satisfactory until the $20^{\text {th }}$ postharvest day, with better results for fruit aroma when stored at $5{ }^{\circ} \mathrm{C}$. CAMPBELL et al. (1987), stored 'Arkin' and 'Golden Star' star fruit under temperatures of 5, 10, 


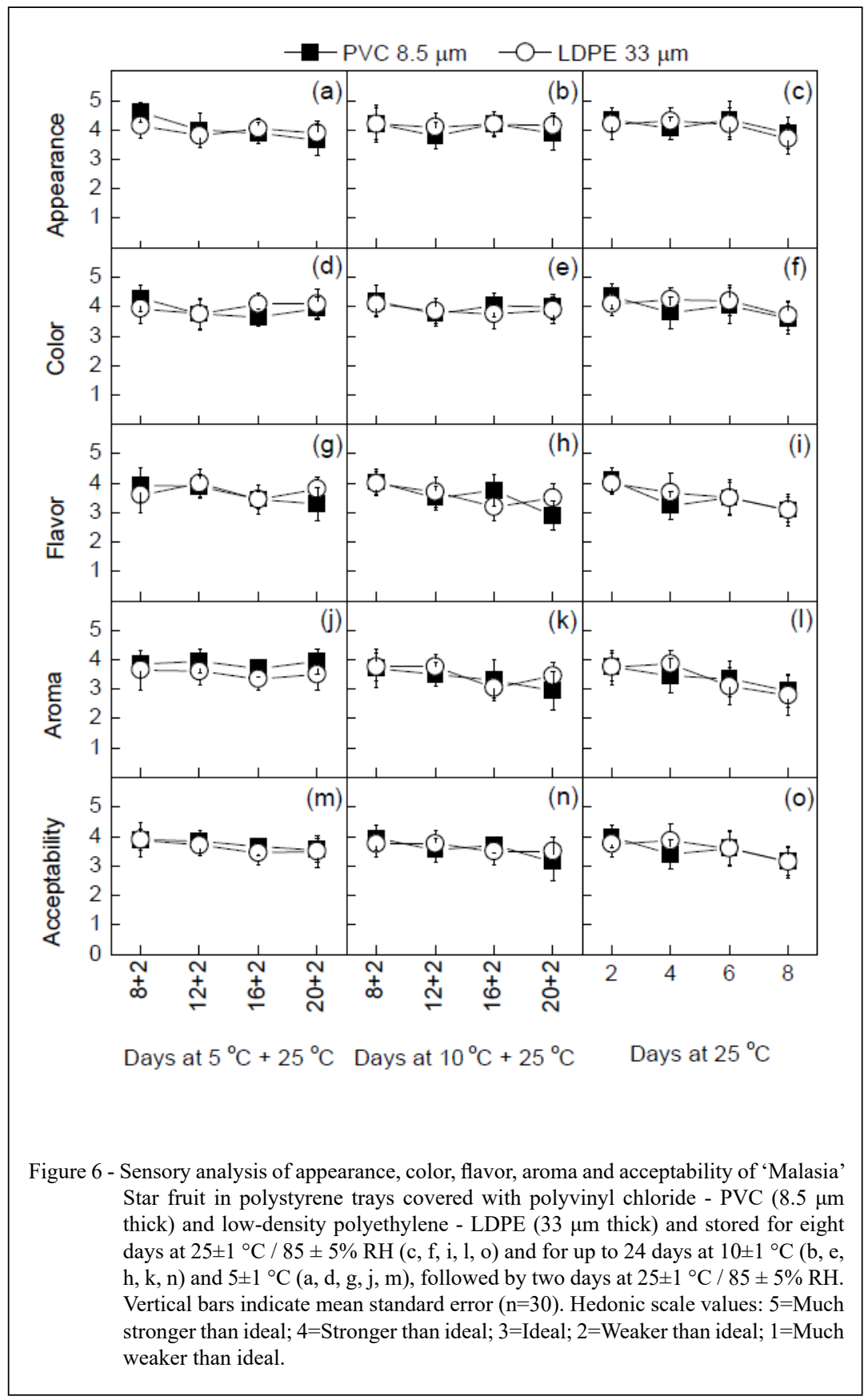

15 and $20^{\circ} \mathrm{C}$ and observed that at $10{ }^{\circ} \mathrm{C}$ fruit had the best appearance, minor decrease in soluble solids and titratable acidity when compared to fruit maintained at 15 and $20{ }^{\circ} \mathrm{C}$. MILLER \& MCDONALD (1997) evaluated temperatures of $5 \pm 0.5^{\circ} \mathrm{C}$ for star fruit and obtained satisfactory results for quality. CANTWELL (2002), however, suggested that the optimum storage temperature and relative humidity were $9-10{ }^{\circ} \mathrm{C}$ and
$85 \%$ to $90 \%$, respectively. DODD \& BOUWER (2014) suggested that the optimum temperature and relative humidity for storage of carambola fruits were $7-10{ }^{\circ} \mathrm{C}$ and $85-95 \%$, respectively. Under these conditions, the storage life of the fruits is approximately $21-35$ days.

According to WANG et al. (2008), among the main effects of chilling injury are irregular ripening, epidermis stains, pulp darkening and increased 
sensibility to rot. Also, a faster senescence and, color and flavor deficiency can be noticed. Although, ALI et al. (2004) observed an accelerated firmness loss after removing the fruit from the refrigeration. WAN \& LAM (1984) observed chilling injury in star fruit with less than $25 \%$ of the skin yellow, after five weeks at $5{ }^{\circ} \mathrm{C}$. Numerous reports have indicated that for this fruit, storage temperature $\leq 5{ }^{\circ} \mathrm{C}$ causes chilling injury (CI), which becomes severe with longer storage times (MILLER \& MCDONALD, 1997; WARREN et al., 2007; CHEN et al., 2017). In the present research, the results of ${ }^{\circ} \mathrm{H}$ angle and firmness (Figure 1), demonstrated that after refrigeration, fruit presented retention of yellow color development and firmness loss. The retention of color development and firmness loss of refrigerated fruit did not affect the fruit acceptance by the consumers (Figure 6). On the contrary, the acceptability test showed that the more advanced was the ripening stage of 'Malasia' star fruit, lower were the grades attributed to the sensory analysis (Figure 6). Therefore, results indicated retention in color development and firmness loss but no cold typical damages were observed in the two days of marketing, emphasizing the refrigeration benefits. The refrigerated fruit reached pulp firmness values close to those that were not maintained in cold storage.

Physico-chemical characteristics of 'Malasia' Star fruit were similar to those observed by other authors with different cultivars. MITCHAM \& MCDONALD (1991), evaluating Arkin cultivar in different ripening stages, reported $11 \mathrm{~N}$ of firmness in full ripen fruit and $40 \mathrm{~N}$ for fruit changing the skin color from green to yellow. It is possible to observe that 'Malasia' Star fruit, even with a lower firmness at harvest, had similar values of firmness when fully ripen, indicating maintenance of fruit firmness during marketing, in comparison to Arkin cultivar. TEIXEIRA et al. (2006), evaluating Star fruit 'Fwang Tung', stored for 9 days at $21^{\circ} \mathrm{C}$, obtained $101{ }^{\circ} \mathrm{H}$. Results indicated that fruit of 'Malasia' studied in this research, presented lower values for ${ }^{\circ} \mathrm{H}$, which means an increased development of yellow color when ripened.

'Malasia' Star fruit can be classified as a low acidity fruit, corresponding to values of $0.2 \%$ and $0.3 \%$, similar to red apples and bananas (CECCHI, 1999), and minor changes in soluble solids content comparatively to other fruit, mainly the ones that accumulate starch during growth. According to WILSON (1990), the best ratio (SS/TA) for consumption is 12.6 ( $8.6 \%$ of SS and $0.69 \%$ of TA), lower than the values found for 'Malasia', indicating a sweeter flavor of this cultivar (Data not shown).

Objective and subjective analysis indicated that the browning problem did not occur in this study.
These results are consistent with the luminosity values (L) which had minor variations throughout the storage (Figure 1G, 1H and 1I). Commercially, this is a positive point. Darkening varies widely according to the cultivar. Studying several star fruit cultivars TEIXEIRA et al. (2006) attributed the lack of darkening to lower phenols content of some cultivars, limiting the oxidation process.

As final considerations, the temperatures of 5 and $10{ }^{\circ} \mathrm{C}$ for 'Malasia' Star fruit did not cause skin darkening, epidermis stains, abnormal ripeness, changes in color, flavor and appearance. Some retention in color and firmness of refrigerated fruit was detected, which did not interfere in commercialization, once this retention was a positive result obtained in sensory analysis. Evaluating the sensory analysis in conjunction with the physicochemical analysis it is valid to consider that fruit stored at $25{ }^{\circ} \mathrm{C}$ had the quality preserved until the sixth day. After this date, the sensory analysis attributed lower grades mainly for fruit appearance, color and aroma. Considering the rot absence, fruit presented maximum quality until the fourth day of storage. Fruit under refrigeration also presented good quality and no rot signs until the $16^{\text {th }}$ day of storage.

\section{CONCLUSION}

When stored at $25{ }^{\circ} \mathrm{C}$ 'Malasia' star fruit packed in PVC $8.5 \mu \mathrm{m}$ and LDPE $33 \mu \mathrm{m}$ had their quality preserved for four days. The storage at 5 and 10 ${ }^{\circ} \mathrm{C}$, regardless of the plastic film, extended 'Malasia' Star fruit shelf-life and allowed fruit conservation for up to 16 days, followed by two days at $25^{\circ} \mathrm{C}$.

\section{BIOETHICS AND BIOSSECURITY COMMITTEE APPROVAL DECLARATION}

We authors of the article entitled "Conservation of 'Malasia' Star fruit associating refrigeration and modified atmosphere" declared, for all due purposes, the project that gave rise to the present data of the same has not been submitted for evaluation to the Ethics Committee of the Universidade de São Paulo, but we are aware of the contents of Resolution No. 466, of December 12, 2012 of the Brazilian National Health Council "http://conselho.saude.gov.br/ resolucoes/2012/Reso466.pdf' if it involves human.

Thus, the authors assume full responsibility for the presented data and are available for possible questions, should they be required by the competent authorities.

\section{ACKNOWLEDGEMENTS}

The research was financed by Fundação de Amparo à Pesquisa do Estado de São Paulo (FAPESP). BMPS has scholarship from Coordenação de Aperfeiçoamento de Pessoal de Nível Superior (CAPES). RCL has scholarship from Fundação de Amparo à Pesquisa do Estado do Amazonas (FAPEAM). 


\section{DECLARATION OF CONFLICT OF INTERESTS}

The authors declare no conflict of interest. The founding sponsors had no role in the design of the study; in the collection, analyses, or interpretation of data; in the writing of the manuscript, and in the decision to publish the results.

\section{AUTHORS' CONTRIBUTIONS}

The authors contributed equally to the manuscript.

\section{REFERENCES}

ALI, Z. M. et al. Low temperature storage and modified atmosphere packaging of carambola fruit and their effects on ripening related texture changes, wall modification and chilling injury symptoms. Postharvest Biology and Technology, v.2, p.181-192, 2004. Available from: <https://doi.org/10.1016/j. postharvbio.2004.02.007>. Accessed: Aug. 06, 2019. doi: 10.1016/j.postharvbio.2004.02.007

CAMPBELL, C. A.; KOCH, K. E. Sugar/acids composition and development of sweet and tart carambola fruit. Journal of The American Society for Horticultural Science, v.114, p.455-457, 1989. Available from: <http://agris.fao.org/agris-search/search. do? recordID=US8924850 > . Accessed: Aug. 05, 2019. ISSN: 0003-1062.

CAMPBELL, C. A. et al. Postharvest response of carambola to storage at low temperatures. Proceedings of Florida State Horticultural Society, v.100, p.272-275, 1987. Available from: <https://www. sciencedirect.com/science/article/abs/pii/092552149390031W $>$. doi: 10.1016/0925-5214(93)90031-W. Accessed: Aug. 10, 2019.

CANTWELL, M. I. Appendix: summary table of optimal handling condition for fresh produce. In: KADER, A. A. Postharvest Technology of Horticultural Crops. University of California, Richmond, CA, p.511-518, 2002. Available from: <https://www.researchgate.net publication/284667891 Summary table of optimal handling conditions_for_fresh_produce>.Accessed: Jul 14, 2019.

CARVALHO, C. R. L. et al. Análises químicas de alimentos. Campinas: Instituto de Tecnologia de Alimentos, 1990.

CECCHI, H. M. Fundamentos teóricos e práticos em análise de alimentos. Campinas: Ed. da Unicamp, 1999.

CHEN, S-W et al. Effect of harvest season, maturity and storage temperature on storability of carambola. Scientia Horticulturae, v.220, p.42-51, 2017. Available from: <https://doi.org/10.1016/j. scienta.2017.03.047>. Accessed: Aug. 06, 2019. doi: 10.1016/j. scienta.2017.03.047.

CRUZ, R. G. et al. Conservação refrigerada de carambolas em embalagens plásticas. Revista Brasileira de Engenharia Agrícola e Ambiental. v.2, p.279-282, 2001. Available from: <http://www. scielo.br/scielo.php?script $=$ sci arttext\&pid $=\mathrm{S} 1415436620010$ $00200017 \& \operatorname{lng}=\mathrm{en} \& \mathrm{nrm}=\mathrm{iso}>$. Accessed: Aug. 06, 2019. doi: $10.1590 /$ S1415-43662001000200017.

DODD, M. C.; BOUWER, J. J. The supply value chain of fresh produce from field to home: refrigeration and other supporting technology. In: FLORKOWSKI, W.J. et al. Postharvest Handling: A Systems Approach. Academic Press, San Diego,
CA, p.449-483, 2014. Available from: <https://www.sciencedirect. com/science/article/pii/B9780124081376000168>. Accessed: Jul 16, 2019. doi: 10.1016/B978-0-12-408137-6.00016-8.

MILLER, W. R.; MCDONALD, R. E. Carambola quality after ethylene and cold treatments and storage. American Society of Horticultural Science. v.5, p.897-899, 1997. Available from: $<$ https://doi.org/10.21273/HORTSCI.32.5.897>. Accessed: Aug. 06, 2019. doi: 10.21273/HORTSCI.32.5.897.

MITCHAM, E. J.; MCDONALD, R. E. Characterization of the ripening of carambola (Averrhoa carambola L.) fruit. Proceedings of The Florida State Horticultural Society. v.104, p.104-108, 1991. Available from: <http://agris.fao.org/ agris-search/search.do? recordID $=\mathrm{US} 19950133268>$. Accessed: Jul 23, 2019. ISSN: 0886-7283.

NEVES, L. C. et al. Armazenagem em atmosfera modificada passiva de carambola-azeda (Averrhoa carambola L.) cv. 'Golden Star'. Revista Brasileira de Fruticultura. v.1, p.13-16, 2004. Available from: $<$ http://www.scielo.br/scielo.php?script=sci_arttext\&pid=S010029452004000100006\&lng=en\&nrm=iso $>$. Accessed: Aug. 06, 2019. doi: 10.1590/S0100-29452004000100006.

REVEL, L.; THOMPSON, A. K. Carambola in controlled atmospheres. Tropic Fruits Newsletter Inter-American Institute for Cooperation on Agricultural. v.7, 1994. ISSN: 9781845936464.

TEIXEIRA, G. H.A.; DURIGAN, J. F. Controle do amadurecimento de carambolas com 1-MCP. Revista Brasileira de Fruticultura. v.3, p.339-342, 2006. Available from: <http://www.scielo.br/ scielo.php?script $=$ sci_arttext\&pid $=\mathrm{S} 010029452006000300001 \& 1$ $\mathrm{ng}=\mathrm{en} \& \mathrm{nrm}=\mathrm{iso}>$. Accessed: Aug. 06, 2019. doi: 10.1590/S010029452006000300001 .

TEIXEIRA, G. H. A. et al. Cultivar affects browning susceptibility of freshly cut star fruit slices. Scientia Agricola. v.1, p.1-4, 2006. Available from: <http://www.scielo.br/scielo. php? script $=$ sci arttext\&pid $=$ S010390162006000100001\&lng= en\&nrm=iso $>$. Accessed: Aug. 06, 2019. doi: 10.1590/S010390162006000100001

WAN, C. K.; LAM, P. F. Biochemical changes, use of polyethylene bags, and chilling injury of carambola (Averrhoa carambola L.) stored at various temperatures. Pertanika. v.7, p.39-46, 1984. Available from: <http://psasir.upm.edu.my/id/eprint/2247/>. Accessed: Aug. 06, 2019.

WANG, B. et al. Reduced chilling injury in mango fruit by 2,4-dichlorophenoxyacetic acid and the antioxidant response. Postharvest Biology Technology. v.2, p.172-181, 2008. Available from: $<$ https://doi.org/10.1016/j.postharvbio.2007.10.005>. Accessed: Aug. 06, 2019. doi: 10.1016/j.postharvbio.2007.10.005.

WARREN, O. et al. Harvesting carambola at different ripeness stages affects postharvest quality. Proceedings of The Florida State Horticultural Society. v.120, p.256-258, 2007. Available from: $\quad<$ https://journals.flvc.org/fshs/article/view/86233>. Accessed: Sep. 9, 2019. ISSN: 0886-7283.

WILSON, C. W. Carambola and Bilinbi. In: NAGY, S. et al. Fruits of tropical and subtropical origin: composition, properties and uses, Lake Alfred: Florida Science Source, 1990. P.277301. Available from: <https://www.cabdirect.org/cabdirect/ abstract/19916780766>. Accessed: Jul 29, 2019. Record Number: 19916780766. 